\title{
Migracja ukraińskich pracowników w Polsce podczas pandemii COVID-19
}

\section{Streszczenie}

Około 1 mln migrantów przebywa obecnie w Polsce, głównie są to pracownicy z Ukrainy. Restrykcje w przekroczeniu granic Rzeczypospolitej Polskiej w dobie pandemii COVID-19 oraz perspektywa recesji gospodarczej stały się czynnikami motywującymi do opuszczenia polskiego rynku pracy przez pracowników z Ukrainy. Ograniczenie handlu i usług $\mathrm{w}$ wielu polskich przedsiębiorstwach wymusiło redukcję personelu w obawie przed bankructwem. Przedsiębiorcy, którzy zwolnili swoich pracowników nie czekając na wsparcie rządu w postaci „tarczy antykryzysowej”, postawili najczęściej na osoby o najniższym stażu pracy, niemające umów o pracę i pochodzące z mniejszości narodowych. Skutki gospodarcze i polityczne takich decyzji odczuje w dłuższej perspektywie cały rynek pracy. Analiza migracji ukraińskich pracowników w Polsce po wybuchu epidemii COVID-19 pozwoli ocenić skalę tej migracji i podjąć próbę odpowiedzi na pytanie: Czy polscy przedsiębiorcy działają w duchu interesu publicznego, czy jednak uprzedzeń wobec obcej siły roboczej? Badanie ma na celu analizę reakcji służb i instytucji publicznych na migracje spowodowane rozprzestrzenianiem się wirusa SARS-CoV-2. Dane wskazują, że nie radziły sobie one z wydaniem nowych kart pobytu, zezwoleń na pracę. Wystąpiły komplikacje związane z przekraczaniem granicy. Wszystko to świadczy o słabym przygotowaniu służb granicznych do migracji o tak dużej skali. Ponadto doszło do wzrostu liczby zwolnień obywateli

1 Uniwersytet Medyczny im. Karola Marcinkowskiego w Poznaniu, Zakład Immunobiologii, e-mail: m.bartoszkiewicz@ump.edu.pl, https://orcid.org/0000-0002-8728-5998 
Ukrainy w czasie trwania pandemii. Zauważono również wystąpienie przejawów rasizmu w społeczeństwie. W efekcie nasiliła się migracja.

Słowa kluczowe: migracja, SARS-CoV-2, pandemia COVID-19, cudzoziemcy, Ukraińcy, umowy cywilnoprawne, zwolnienia

Kody kwalifikacji JEL: J11, J61, J64

\title{
Migration of Ukrainian workers in Poland during the COVID-19 pandemic
}

\begin{abstract}
About 1 million migrants currently reside in Poland, and mainly they are workers from Ukraine. Restrictions on crossing the borders of the Republic of Poland in the time of the COVID-19 pandemic and the prospect of economic recession have become motivating factors for Ukrainian workers to leave the Polish labor market. Restrictions of trade and services in many Polish enterprises forced the reduction of their staff in fear of bankruptcy. Entrepreneurs who dismissed their employees without waiting for government support in the form of the "anti-crisis shield" most often focused on people with the lowest seniority, who are not on employment contracts, and those coming from national minorities. The analysis of the migration of Ukrainian workers in Poland during the COVID-19 outbreak will allow us to assess the scale of this migration and attempt to answer the question whether Polish entrepreneurs act in the spirit of national patriotism or racism. The study aims to analyze the response of public services and institutions as a result of migration caused by the spread of the SARS-CoV-2 virus. Migration and compilations related to crossing the state border have revealed the poor preparation of border services for such a large scale of migration. There has also been an increase in the number of cases of national racism in the society.
\end{abstract}

Keywords: migration, SARS-CoV-2, COVID-19 pandemic, foreigners, Ukrainians, civil law contracts, layoffs

JEL Classification Codes: J11, J61, J64

Celem artykułu jest zbadanie skali migracji mniejszości narodowych w Polsce $\mathrm{w}$ dobie pandemii wirusa SARS-CoV-2. Opierając się na danych pochodzących z Głównego Urzędu Statystycznego oraz doniesieniach medialnych, przeanalizowano ruch migracyjny. Artykuł przedstawia prognozy gospodarcze dotyczące wpływu pandemii COVID-19 na gospodarkę, analizę migracji w Polsce oraz szczegółową charakterystykę 
migracji Ukraińców w Polsce podczas pandemii. W dalszej części artykułu rozpatrywana jest możliwość stworzenia tarczy antykryzysowej dla cudzoziemców.

W Polsce pierwszy przypadek zachorowania na COVID-19, chorobę wywoływaną przez wirus SARS-CoV-2, potwierdzono 4 marca 2020 r., a 20 marca zgodnie $\mathrm{z}$ rozporządzeniem ministra zdrowia w Polsce wprowadzono stan epidemii. Do 8 stycznia 2021 r. odnotowano w Polsce 1,36 mln przypadków zakażenia, z czego 30542 osoby zmarły (Ministerstwo Zdrowia, 2020; John Hopkins University, 2020).

Wiele państw wprowadziło liczne restrykcje w związku z koniecznością zminimalizowania ryzyka rozprzestrzeniania się wirusa (WHO, 2020). W związku z pandemią m.in. ograniczono swobodne przemieszczanie się, nakazano noszenie maseczek ochronnych, wprowadzono kwarantanny i godziny policyjne, odwołano imprezy sportowe, kulturalne i uroczystości religijne. W strefie Schengen UE przywrócono wewnętrzne granice państw, ograniczono ruch graniczny lub zamknięto granice (Reuters, 2020). Wiele państw ograniczyło wymiar funkcjonowania placówek edukacyjnych, wprowadzono nauczanie zdalne (UNESCO, 2020).

Pandemia spowodowała problemy społeczno-gospodarcze, które dotknęły cały świat. Polska podobnie jak inne państwa członkowskie UE wprowadziła wiele restrykcji związanych z przeciwdziałaniem rozprzestrzeniania się wirusa SARS-CoV-2. Sejm Rzeczypospolitej Polskiej 2 marca 2020 r. przyjął ustawę zwaną potocznie „specustawą koronawirusową", która umożliwia polskiemu rządowi użycie w walce z COVID-19 i jego skutkami zwiększonych środków administracyjnych, budżetowych i epidemiologicznych (Dz.U. z 2020 r. poz. 374).

Restrykcje dotknęły wielu sfer życia społecznego, stały się ogromnym utrudnieniem w normalnym funkcjonowaniu społeczeństw. Dla światowych gospodarek wprowadzone ograniczenia w sferze handlu to groźba zbliżającego się gigantycznego kryzysu. Za początek wpływu SARS-CoV-2 na gospodarkę trzeba uznać spadki notowań na światowych giełdach, które były największe w skali kilku lat (BBC, 2020). W Polsce Giełda Papierów Wartościowych w Warszawie odnotowała rekordowy spadek od czterech lat (Frączyk, 2020). Ceny ropy naftowej zanotowały 9 marca 2020 r. największy jednodniowy spadek od 30 lat. Szacuje się, że tylko przez pierwsze dni marca ze światowej giełdy wyparowało blisko 9 bln USD (He, Duffy, Horowitz, 2020).

COVID-19 dotknął społeczności, firmy i organizacje na całym świecie, wpływając na rynki finansowe i globalną gospodarkę. Nieskoordynowane reakcje rządowe i blokady doprowadziły do zakłócenia łańcucha dostaw na wielu rynkach (Nicola et al., 2020; 185-193).

Unia Europejska (UE) zaproponowała pakiet ratunkowy w wysokości do $540 \mathrm{mld}$ EUR, aby zminimalizować negatywne skutki ekonomiczne COVID-19 (Garside, 2020). Pandemia spowodowała, że rządy wielu państw na świecie nałożyły ograniczenia 
na wyjazdy do państw dotkniętych COVID-19, zawieszając na czas nieokreślony podróże turystyczne, pracownicze i wizy imigracyjne. Niektóre państwa nałożyły całkowity zakaz transportu wewnętrznego lub zewnętrznego we wszystkich formach. W szczycie pandemii w Europie większość samolotów latało prawie pustych $\mathrm{z}$ powodu nałożonych restrykcji w komunikacji lotniczej. Poprzez wprowadzone ograniczenia wiele linii lotniczych zostało zmuszonych do czasowego zawieszenia działalności, np. Air Baltic, Polskie Linie Lotnicze LOT, La Compagnie i Scandinavian Airlines (Ozili i Arun, 2020). Zamrożenie gospodarki, niepewność przedsiębiorców i groźba dużego wzrostu liczby zakażeń doprowadziły w Polsce do wstrzymania pracy dla wielu osób w I i II kwartale 2020 r.

\section{Wstępne prognozy gospodarcze dotyczące wpływu pandemii COVID-19 na gospodarkę}

McKibbin i Fernando (2020) przeprowadzili analizę wpływu pandemii COVID19 na gospodarkę, zakładając siedem scenariuszy. Wskazali, że skutki gospodarcze można ograniczyć inwestycjami publicznymi w sektor ochrony zdrowia.

Polska gospodarka powinna w mniejszym stopniu odczuć skutki pandemii niż inne kraje europejskie. Po pierwsze dlatego, że w porównaniu chociażby z niemiecką (dla której prognozowano zmniejszenie PKB od 0,1\% do 1,7\% w 2020 r.) polska gospodarka jest mniej zależna od eksportu i słabiej powiązana gospodarczo z Chinami (Sieroń, 2020). W raporcie o inflacji z marca 2020 r. Narodowy Bank Polski obniżył wzrost polskiego PKB w 2020 r. z 3,6\% do 3,2\% (NBP, 2020). Prognozy gospodarcze są bardzo ostrożne ze względu na nadal trwającą pandemię. Najbardziej dotkliwą prognozą dla pracowników są zwolnienia grupowe spowodowane negatywnym wpływem wirusa SARS-CoV-2 na gospodarkę.

\section{Zarys danych o migracjach w Polsce}

Po wstąpieniu Polski do UE w 2004 r. migracja zewnętrzna zaczęła z roku na rok przeobrażać się z migracji krótkookresowej w długookresową, która jest bardziej charakterystyczna dla krajów Europy Zachodniej. Wprowadzenie przez rząd rozwiązań zachęcających do przyjazdu cudzoziemców do Polski ma swoje uwarunkowania społeczno-ekonomiczne. Jednym z głównych jest niekorzystny trend demograficzny.

W Polsce widoczny jest niski przyrost naturalny - jeden z najniższych współczynników dzietności wśród państw UE. Dochodzi także do spadku liczby osób 
w wieku produkcyjnym, co stawia pod znakiem zapytania perspektywę rozwoju polskiej gospodarki. Dodatkowym czynnikiem, który wpłynął na taki stan, jest dynamiczna emigracja zarobkowa Polaków po 2004 r. do państw Europy Zachodniej (MSWiA, 2019). W przypadku Polski oznacza to, że jeśli w najbliższych latach nie nastąpi zwiększenie liczby pracujących, to polskiemu społeczeństwu nie uda się zachować obecnego poziomu rozwoju. W tym kontekście coraz częściej pojawiają się postulaty jeszcze szerszego otwarcia Polski na imigrantów, np. Związek Pracodawców Polskich postuluje „mądrą absorpcję imigrantów z krajów sąsiadujących z Polską" (Fandrejewska-Tomczyk, 2019).

Jednym z celów polityki migracyjnej Polski jest stworzenie kompleksowego systemu integracji i asymilacji cudzoziemców. Polska polityka migracyjna jest w głównej mierze ukierunkowana na obywateli zza wschodniej granicy UE. Rosnąca w Polsce liczba zawodów deficytowych, związanych przede wszystkim z branżą budownictwa, transportu i niektórych usług, stwarza lukę na rynku pracy, która może zostać wypełniona przez cudzoziemców.

Na polskim rynku pracy może przebywać obecnie ponad 1 milion cudzoziemskich pracowników (dane nieoficjalne), głównie z Ukrainy i pozostałych państw postradzieckich (Bereźnicki, 2019). Pracownicy z Ukrainy są obecnie zatrudnieni w co dziesiątej polskiej firmie (zatrudnia ich 39\% dużych firm, 21\% średnich i 6\% małych). Najwięcej pracowników zza wschodniej granicy pracuje w produkcji oraz usługach (Banyś, Kuźnik, 2018). Ewolucja migracji krótkookresowej w osiedleńczą dla cudzoziemców na terenie Polski to długotrwały proces społeczno-ekonomiczny. Zachęty oraz uatrakcyjnienie rynku pracy mogą być czynnikami, które wpłyną na większy odsetek migracji osiedleńczych. Nadal duża część cudzoziemców nie chce pozostawać w Polsce na stałe.

Analizując migrację na terenie Polski w latach 2014-2019, posłużono się bazą danych Urzędu do Spraw Cudzoziemców. Pięcioletnia obserwacja (2014-2019) danych wskazuje na wzrost migracji o $212 \%$ bez podziału na rodzaj pobytu (tabela 1). Biorąc pod uwagę dwa najczęstsze rodzaje pobytów (stały i czasowy) cudzoziemców w Polsce, zauważamy wzrost pobytu czasowego o $227 \%$, natomiast wzrost pobytu stałego o $119 \%$.

Tabela 1. Cudzoziemcy w Polsce w latach 2014-2019

\begin{tabular}{|l|r|r|r|r|r|r|}
\hline \multicolumn{1}{|c|}{ Cudzoziemcy w Polsce } & \multicolumn{1}{c|}{2014} & 2015 & 2016 & 2017 & \multicolumn{1}{c|}{2018} & 2019 \\
\hline Pobyt czasowy & 42548 & 64938 & 86611 & 103221 & 114036 & 139345 \\
\hline Pobyt stały & 6659 & 9880 & 9045 & 13306 & 14407 & 14559 \\
\hline Razem & 49207 & 74818 & 95656 & 116527 & 128443 & 153904 \\
\hline
\end{tabular}

Źródło: UDSC (2020). 
Cudzoziemcy przybywający do Polski w ostatnich pięciu latach najczęściej pochodzili z Ukrainy, to właśnie oni stanowili $65 \%$ wszystkich obcokrajowców. Kobiety stanowiły $43 \%$ przyjezdnych, a mężczyźni 57\%. Zanotowano wzrost migracji obywateli Ukrainy w latach 2014-2019 o 420\%, pobyt czasowy wzrósł o 484\%, a pobyt stały o 105\%. Najwięcej osób osiedliło się na terenie woj. mazowieckiego, co stanowi 40\% wszystkich Ukraińców, drugim województwem pod tym względem jest woj. małopolskie - 19\% (tabela 2).

Tabela 2. Liczba obywateli Ukrainy w Polsce w latach 2014-2019

\begin{tabular}{|l|r|r|r|r|r|r|}
\hline \multicolumn{1}{|c|}{ Ukraina } & \multicolumn{1}{c|}{2014} & \multicolumn{1}{c|}{2015} & \multicolumn{1}{c|}{2016} & \multicolumn{1}{c|}{2017} & \multicolumn{1}{c|}{2018} & \multicolumn{1}{c|}{2019} \\
\hline Pobyt czasowy & 17104 & 37834 & 57247 & 70271 & 80215 & 99919 \\
\hline Pobyt stały & 3484 & 6730 & 5920 & 7868 & 7712 & 7168 \\
\hline Razem & 20588 & 44564 & 63167 & 78139 & 87927 & 107087 \\
\hline Kobiety & 13404 & 21649 & 34593 & 49728 & 66355 & 91333 \\
\hline Mężczyźni & 9688 & 24763 & 45942 & 70727 & 93387 & 120941 \\
\hline Mazowieckie & 8268 & 14452 & 23107 & 31626 & 38279 & 44610 \\
\hline Małopolskie & 2945 & 6562 & 10479 & 13973 & 17067 & 23916 \\
\hline
\end{tabular}

Źródło: UDSC (2020).

Obserwujemy intensywny wzrost migracji obywateli Ukrainy do Polski w ostatnich pięciu latach. Wzrost migracji o 420\% (od 2014 r. do 2019 r.) jest niewątpliwe ogromnym wyzwaniem logistycznym dla Polski, ale również ogromną szansą na rozwój rynku pracy. Dla Ukrainy polski rynek w ostatnich latach stał się głównym celem nie tylko migracji czasowej, ale również stałej, co zachęca przedsiębiorców i samorządy do inwestowania w kapitał mniejszości narodowych.

Dane zaprezentowane w tabelach 1 i 2 dotyczą tylko zarejestrowanych pobytów stałych i czasowych cudzoziemców, nie analizowano innych rejestrów, ponieważ głównym celem artykułu było wskazanie dynamiki wzrostu osiedlania się cudzoziemców, w tym obywateli Ukrainy, w Polsce.

\section{Wybrane aspekty migracji obywateli Ukrainy w pierwszym okresie pandemii COVID-19}

Do analizy migracji Ukraińców w dobie pandemii wirusa SARS-CoV-2 wykorzystano dane Głównego Urzędu Statystycznego (GUS, 2020) i Straży Granicznej (KGSG, 2020). Przeanalizowano pierwsze dwa miesiące pandemii (marzec i kwiecień 2020 r.). W tabeli 3 przedstawiono dane przyjazdów i wyjazdów cudzoziemców do 
i z Polski od 1 marca do 30 kwietnia 2020 r. Do porównania wybrano oprócz Ukrainy trzy kraje o największej liczbie ich obywateli w Polsce.

W tabeli 3, opartej na danych pochodzących ze Straży Granicznej w okresie od 1 marca do 30 kwietnia, widać, że ogólna liczba przyjazdów Ukraińców do Polski w stosunku do wyjazdów zmniejszyła się o 28\%. Wyjechało ok. 160 tys. osób pochodzenia ukraińskiego. Aby odnieść dane do poprzedniego roku, porównano je z I kwartałem 2019 r. w liczbie przekroczeń granicy przez Ukraińców w Polsce (tabela 4).

Tabela 3. Przyjazdy i wyjazdy cudzoziemców do i z Polski od 1 marca do 30 kwietnia $2020 \mathrm{r}$.

\begin{tabular}{|l|c|c|c|}
\hline \multicolumn{1}{|c|}{ Kraj } & Przyjazd & Wyjazd & Różnica (\%) \\
\hline Ukraina & 407786 & 567828 & -28 \\
\hline Białoruś & 162719 & 196706 & -18 \\
\hline Rosja & 41791 & 51308 & -19 \\
\hline Pozostałe & 53228 & 71184 & -26 \\
\hline
\end{tabular}

Źródło: GUS (2020).

Tabela 4. Osobowy ruch graniczny w I kwartale 2020 r. i I kwartale 2019 r.

\begin{tabular}{|l|c|c|c|}
\hline \multicolumn{1}{|c|}{ Ukraina } & I kwartał 2020 r. & I kwartał 2019 r. & Różnica (\%) \\
\hline Z Polski & 1835302 & 2002368 & -8 \\
\hline Do Polski & 2011389 & 2330722 & -14 \\
\hline Razem & 3846691 & 4333090 & -11 \\
\hline Ogólnie (na granicy zewnętrznej UE) & I kwartał 2020 r. & I kwartał 2019 r. & Różnica \\
\hline Z Polski & 3510627 & 3843919 & -9 \\
\hline Do Polski & 3621821 & 4163266 & $-13 \%$ \\
\hline Razem & 7132448 & 8007185 & $-11 \%$ \\
\hline
\end{tabular}

Źródło: GUS (2020).

Analizując tabelę 4, możemy zaobserwować ogólny spadek migracji obywateli Ukrainy w stosunku do poprzedniego roku o 11\% (wjazdy i wyjazdy). W I kwartale 2020 r. wjechało do Polski o 14\% mniej Ukraińców niż w I kwartale 2019 r., natomiast wyjechało o $8 \%$ mniej niż w analogicznym kwartale zeszłego roku. Dane dotyczące cudzoziemców na granicy zewnętrznej UE odzwierciedlają podobny trend jak wśród obywateli Ukrainy - ogólny spadek migracji notujemy o 11\%, w tym do Polski przyjechało o 13\% mniej, a wyjechało z Polski o 9\% mniej cudzoziemców. Wykorzystano również dane pochodzące z rejestru Zakładu Ubezpieczeń Społecznych (ZUS) dotyczące liczby ubezpieczonych (ubezpieczenie emerytalne i rentowe), którzy legitymowali się innym obywatelstwem niż polskie. Dane te pozwolą precyzyjniej określić 
spadek bądź wzrost liczby zatrudnionych Ukraińców w czasie pandemii i porównać z je poprzednimi miesiącami.

Tabela 5. Rejestr ZUS ubezpieczonych cudzoziemców w Polsce

\begin{tabular}{|l|c|c|c|c|}
\hline \multicolumn{1}{|c|}{ Rejestr ubezpieczonych } & Grudzień 2019 r. & Luty 2020 r. & Marzec 2020 r. & Kwiecień 2020 r. \\
\hline Ukraińcy & 479113 & 493138 & 484753 & 449298 \\
\hline Ogólnie & 651506 & 670172 & 662253 & 622314 \\
\hline
\end{tabular}

Źródło: GUS (2020).

Analizując dane zawarte w tabeli 5 dotyczące rejestru ubezpieczonych, którzy legitymowali się innym obywatelstwem niż polskie, możemy odnotować spadek liczby osób zgłoszonych do ubezpieczenia emerytalnego i rentowego. Dla obywateli Ukrainy, porównując luty 2020 r. z kwietniem 2020 r., notujemy spadek o 8,9\%, dla ogólnej liczby zgłoszonych do ubezpieczenia cudzoziemców spadek ten wynosi 7,2\%.

Dane przedstawione w tabeli 5 nie odzwierciedlają rzeczywistości, ponieważ nieznana jest liczba osób niezarejestrowanych. Informacje Straży Granicznej nie wyszczególniają ewentualnych wielokrotnych przekroczeń granicy przez jednego cudzoziemca, co może powodować wyniki fałszywie dodanie. Trzeba pamiętać, że liczba cudzoziemców, w tym obywateli Ukrainy, przebywających na terytorium Rzeczypospolitej Polskiej może być wyższa.

\section{Tarcza antykryzysowa dla cudzoziemców w pierwszym okresie pandemii COVID-19}

Pandemia COVID-19 zmusiła wielu cudzoziemców do wyjazdu z Polski. Część z nich musiała podjąć trudną decyzję o opuszczeniu Polski z uwagi na czynniki osobiste (np. utrata pracy, troska o rodzinę czy też strach przed rozprzestrzenianiem się wirusa). Polski rząd w ustawie o tarczy antykryzysowej (z dnia 14 maja 2020 r.) wprowadził rozwiązania przewidziane dla cudzoziemców przebywających na terytorium RP. Na początku pandemii przedłużono im okres ważności zezwoleń na pobyt czasowy, wiz krajowych, zezwoleń na pracę czy kart pobytu o 30 dni następujących po odwołaniu przez ministra zdrowia stanu epidemii bądź stanu zagrożenia epidemicznego. Zmiany te pozwoliły na legalizację pobytu tym osobom, którym okres ważności pobytu kończył się w czasie stanu epidemii, a ze względu na ograniczoną działalność urzędów przedłużenie takich pobytów nie było możliwe.

Ponadto w ramach uregulowań tarczy antykryzysowej umożliwiono im pracę zdalną, obniżenie wymiaru pracy o $20 \%$ (nie więcej niż do $1 / 2$ etatu) oraz wprowadzono 
rotację pracowników w celu zminimalizowania ryzyka rozprzestrzeniania się wirusa SARS-CoV-2. Cudzoziemcy, podobnie jak obywatele Polski, otrzymali możliwość przedłużenia terminu otrzymywania pomocy socjalnej i opieki medycznej, jeśli upływał on w okresie obowiązywania stanu zagrożenia epidemicznego albo stanu epidemii. Uległy również zmianie warunki uzyskiwania zezwolenia na pracę: cudzoziemiec może wykonywać pracę bez konieczności zmiany zezwolenia czy uzyskania nowego zezwolenia. W przypadku obywateli: Armenii, Białorusi, Gruzji, Mołdawii, Rosji i Ukrainy odstępuje się od wymogu osobistego złożenia dokumentów w związku z ubieganiem się o wizę. Wszystkie powyższe rozwiązania wprowadzone przez rząd Rzeczypospolitej Polskiej mają na celu zatrzymać odpływ cudzoziemców z polskiego rynku pracy.

Za pierwszy przejaw masowych wyjazdów Ukraińców można uznać kolejki tworzące się na przejściach granicznych, przykładem jest przejście graniczne Korczowa-Krakowiec na granicy z Ukrainą, gdzie pod koniec marca ustawiały się kilometrowe kolejki (Jargiło, 2020). Panika wywołana rozprzestrzenianiem się wirusa spowodowała nagły wyjazd obywateli Ukrainy z Polski. Szacunkowa liczba Ukraińców przebywających w Polsce to ok. 1,2 mln, z czego większość jest zatrudniona na tzw. „elastycznych etatach". Kryzys na rynku pracy uderza przede wszystkim w osoby na tzw. śmieciówkach, osoby $\mathrm{z}$ agencji pracy tymczasowej oraz pracujące wahadłowo w ruchu bezwizowym. Szacuje się, że 99\% osób zatrudnionych w agencji pracy tymczasowej to cudzoziemcy. Ukraińcy najczęściej są zatrudniani przez polskich przedsiębiorców na umowach cywilno-prawnych, ponieważ taką formę preferuje się w gastronomii, handlu, sektorze budowlanym, a te branże są w pierwszej kolejności wybierane przez Ukraińców (Polskie Forum HR, 2019).

Głównym problemem dla cudzoziemców w momencie utraty pracy jest okres 30 dni na znalezienie nowej - jeśli się to nie uda, według przepisów osoba ta musi wyjechać. Pierwsza ustawa antykryzysowa została wprowadzona 1 kwietnia 2020 r., ale dopiero drugi projekt, który wszedł w życie 17 kwietnia 2020 r., rozszerzający ustawę antykryzysową, zawierał rozwiązania dla cudzoziemców, w tym dotyczące przedłużenia pobytu.

$* * *$

Pandemia COVID-19 niewątpliwie zmusiła część cudzoziemców do opuszczenia Polski. Wyjeżdżali również z uwagi na bardzo ubogie rozwiązania pomocowe w I wersji ustawy antykryzysowej. Obywatele Ukrainy mają kolejne problemy $\mathrm{w}$ funkcjonowaniu na polskim rynku pracy, ponieważ pracują przeważnie na zasadzie umów cywilnoprawnych. Tym samym pracodawcy mogą je łatwo rozwiązywać, bez okresu wypowiedzenia czy wypłaty świadczeń. Kolejnym problemem 
pozostaje sytuacja osób, które pracują w szarej strefie. To one w pierwszej kolejności w przypadku kłopotów firmy są zwalniane. Do powrotu do Polski może zachęcić cudzoziemców wyeliminowanie szarej strefy i „umów śmieciowych” na polskim rynku pracy.

Ponadto w okresie COVID-19 doszło do wzrostu liczby incydentów ksenofobicznych, antysemickich i rasistowskich. Zdecydowana większość z nich wyrażana była online - w mediach społecznościowych (Facebook, Twitter), w filmach na YouTube oraz komentarzach do materiałów medialnych (OMZRiK, 2020a; 2020b). Od początku pandemii obserwowano agresywne zachowania części Polaków - mowę nienawiści i dyskryminację wobec osób pochodzenia azjatyckiego (jako rzekomo przenoszących wirusa). Później to negatywne nastawienie rozszerzyło się na inne mniejszości, np. osoby z Ukrainy pracujące i mieszkające w Polsce (Pankowski, Dzięgielewski, 2020), m.in. na popularnym portalu Olx.pl zamieszczono ksenofobiczne ogłoszenie w odniesieniu do Ukraińców. Kolejnym przykładem jest wyrzucenie dwóch kobiet pochodzenia ukraińskiego $\mathrm{z}$ hostelu robotniczego w Kiełczewie. Na przełomie marca i kwietnia na Twitterze nasiliły się ksenofobiczne komentarze dotyczące wyjazdu Ukraińców z Polski. Najczęściej odnosiły się do rozprzestrzeniania przez Ukraińców wirusa SARS-CoV-2 i potrzeby zwalniania takich osób z pracy w polskich przedsiębiorstwach (Pankowski, Dzięgielewski, 2020).

Problem rasizmu w Polsce w ostatnich kilkunastu, kilkudziesięciu latach nie był zauważalny ze względu na niski odsetek cudzoziemców przebywających w naszym kraju. W wyniku zwiększenia się liczby obcokrajowców w Polsce i całej Europie zaczynają się rozprzestrzeniać nastroje ksenofobiczne. Zachowania wobec obcokrajowców w Polsce kwalifikować można jako rasizm, który nie jest już oparty na kategorii rasy (która to kategoria została przez współczesną naukę zanegowana), ale na kryterium przynależności kulturowej. Mechanizmy wykluczania mają więc u źródeł kryterium narodowe (Deutschmann, 2017).

Przypadki zachowań ksenofobicznych raportował również Ośrodek Monitorowania Zachowań Rasistowskich i Ksenofobicznych, w związku z niektórymi z nich zostały skierowane do prokuratury zawiadomienia o możliwości popełnienia przestępstwa (OMZRiK, 2020a; 2020b). Z badań na grupie 1016 dorosłych mieszkańców Polski z 2020 r. wynika, że Polacy największą niechęć odczuwają wobec Arabów i Romów (odpowiednio 65\% i 57\%), w następnej kolejności Rosjan (43\%), Ukraińców (41\%), Rumunów (40\%) i Żydów (33\%) (Omuła-Rudzka, 2020). Liczba zachowań na tle ksenofobicznym [według metodologii monitoringu prowadzonego przez Stowarzyszenie „Nigdy Więcej” - przyp. red.] wzrosła do ponad 600 w latach 20112012, natomiast w okresie 1987-2008 takich zdarzeń zanotowano ok. 2500 (Kornak, 2013). Zauważalny jest zdecydowany wzrost zachowań ksenofobicznych. 
Reasumując, jedną z pierwszych reakcji instytucji publicznych w Polsce dotyczącą cudzoziemców było przedłużenie ważności zezwoleń na pobyt czasowy, wiz krajowych, zezwoleń na pracę czy kart pobytu. Cudzoziemcom, podobnie jak Polakom, umożliwiono pracę zdalną czy obniżenie etatu o $20 \%$. Reakcje te nie powstrzymały części cudzoziemców przed masowym wyjazdem z Polski na początku pandemii COVID-19. Wraz z rozwojem pandemii dalsze badania w aspekcie migracji cudzoziemców w Polsce mogą pozwolić na podjęcie analiz dotyczących ruchu migracyjnego na przestrzeni kilku lat, co może zaowocować reakcjami instytucji publicznych na kryzys migracyjny.

\section{Bibliografia}

Banyś, M., Kuźnik, J. (2018). Barometr Imigracji Zarobkowej - I półrocze 2018. Personnel Service, http://personnelservice.pl/wp-content/uploads/2020/07/BarometrImigracjiZarobkowej_raport.pdf (dostęp: 5.06.2020).

BBC (2020). Global stock markets plunge on coronavirus fears, https://www.bbc.com/news/ business-51612520 (dostęp: 2.06.2020).

Bereźnicki, J. (2019). Ukraińców w Polsce jest prawie 1,3 mln. Dane pochodza z ich własnych smartfonów, https://www.money.pl/gospodarka/ukraincow-w-polsce-jest-prawie-13-mln-dane-pochodza-z-ich-wlasnych-smartfonow-6356796733593217a.html (dostęp: 4.06.2020).

Deutschmann, M. (2017). Rasizm w Polsce w kontekście problemów migracyjnych. Próba diagnozy. Studia Krytyczne, 4: 71-85.

Fandrejewska-Tomczyk, A. (2019). 50 milionów mieszkańców Polski. Konkretne działania, a nie tylko marzenia. Warszawa: Związek Przedsiębiorców i Pracodawców, Fundacja Warsaw Enterprise Institute, http://zpp.net.pl/wp-content/uploads/2019/02/Demografia-wersja-elektroniczna.pdf (dostęp: 4.06.2020).

Frączyk, J. (2020). Koronawirus infekuje giełdy. Na GPW największe spadki od czterech lat, https://businessinsider.com.pl/koronawirus-zarazil-gieldy-najwiekszy-spadek-wig20-od-czterech-lat/4n0klnp (dostęp: 21.06.2020).

Garside, J. (2020). Europe's economic rescue packages worth combined $€ 1.7 \mathrm{tn}$, https://www. theguardian.com/world/2020/mar/19/europes-economic-rescue-packages-worth-combined17tn (dostęp: 3.06.2020).

GUS (Główny Urząd Statystyczny) (2020). Populacja cudzoziemców w Polsce w czasie pandemii COVID-19, https://stat.gov.pl/statystyki-eksperymentalne/kapital-ludzki/populacja-cudzoziemcow-w-polsce-w-czasie-covid-19,12,1.html (dostęp: 5.03.2021).

He, L., Duffy, C., Horowitz, J. (2020). US stocks halted after falling 7\%. Global stocks plunge as oil crashes and coronavirus fear spreads, https:/edition.cnn.com/2020/03/08/investing/ stock-dow-futures-coronavirus/index.html (dostęp: 2.06.2020). 
Jargiło, W. (2020). Duże kolejki na przejściu granicznym w Korczowej. 17 godzin oczekiwania na wjazd do Polski, https://www.rmf24.pl/raporty/raport-koronawirus-z-chin/najnowsze-fakty/news-duze-kolejki-na-przejsciu-granicznym-w-korczowej-17-godzin-o,nId,4406027 (dostęp: 6.06.2020).

John Hopkins University (2020). Coronavirus Resource Center, Coronavirus COVID-19 Global Cases, https://coronavirus.jhu.edu/map.html (dostęp: 1.06.2020).

KGSG (Komenda Główna Straży Granicznej) (2020). Informacja statystyczna za I kwartał 2020 r., https://www.strazgraniczna.pl/pl/granica/statystyki-sg/2206, Statystyki-SG.html (dostęp: 9.03.2021).

Kornak, M. (2013). Rasizm i przemoc - rosnace zagrożenie!, https://www.nigdywiecej.org/ komunikaty/komunikaty/109-rok-2013/2809-rasizm-i-przemoc-rosnace-zagrozenie (dostęp: 20.03.2021).

McKibbin, W., Fernando, R. (2020). The economic impact of COVID-19: Economics in the Time of COVID-19, https://www.incae.edu/sites/default/files/covid-19.pdf\#page $=52$ (dostęp: 4.06.2020).

Ministerstwo Zdrowia (2020). Pierwszy przypadek koronawirusa w Polsce, https://web.archive. org/web/20200304112521/https://www.gov.pl/web/zdrowie/pierwszy-przypadek-koronawirusa-w-polsce (dostęp: 1.06.2020).

MSWiA (Ministerstwo Spraw Wewnętrznych i Administracji) (2019). Polityka migracyjna Polski, https://interwencjaprawna.pl/wp-content/uploads/2019/06/Polityka-migracyjna-Polski-wersja-ostateczna.pdf (dostęp: 4.06.2020).

NBP (Narodowy Bank Polski) (2020). Raport o inflacji, https://www.nbp.pl/polityka_pieniezna/dokumenty/raport_o_inflacji/raport_marzec_2020.pdf (dostęp: 1.06.2020).

Nicola, M., Alsafi, Z., Sohrabi, C., Kerwan, A., Al-Jabir, A., Iosifidis, C., Agha, M., Agha, R. (2020). The socio-economic implications of the coronavirus pandemic (COVID-19): A review, International Journal of Surgery, 78(6): 185-193, DOI: 10.1016/j.ijsu.2020.04.018.

Omuła-Rudzka, M. (2020). Komunikat z badań CBOS. Stosunek do innych narodów. Warszawa: Fundacja Centrum Badania Opinii Społecznej, https://www.cbos.pl/SPISKOM. POL/2020/K_031_20. PDF (dostęp: 9.03.2021).

OMZRiK (Ośrodek Monitorowania Zachowań Rasistowskich i Ksenofobicznych) (2020). Akt oskarżenia za znieważenie Ukraińców, https://omzrik.pl/akt-oskarzenia-za-zniewazanie-ukraincow (dostęp: 9.03.2021).

OMZRiK (Ośrodek Monitorowania Zachowań Rasistowskich i Ksenofobicznych) (2020). Groził rodzinie z Ukrainy, stanie przed sądem, https://omzrik.pl/grozil-rodzinie-z-ukrainy-stanie-przed-sadem (dostęp: 9.03.2021).

Ozili, PK., Arun, T. (2020). Spillover of COVID-19: Impact on the Global Economy, SSRN, DOI: $10.2139 /$ ssrn.3562570.

Pankowski, R., Dzięgielewski, J. (2020). Polska: Kryzys COVID-19 a mowa nienawiści, https:// www.nigdywiecej.org/docstation/com_docstation/172/kryzys_covid_19_a_mowa_nienawisci.pdf (dostęp: 5.01.2021). 
Pankowski, R., Tatar, A., Dzięgielewski, J. (2020). Wirus nienawiści: „Brunatna Księga” czasu epidemii, https://www.nigdywiecej.org/docstation/com_docstation/172/wirus_nienawisci_brunatna_ksiega_czasu_epidemii.pdf (dostęp: 5.01.2021).

Polskie Forum HR (2019). Rynek agencji zatrudnienia w 2019, https://polskieforumhr.pl/ wp-content/uploads/2020/04/rynek-agencji-zatrudnienia-2019.pdf (dostęp: 9.03.2021).

Reuters (2020). Coronavirus: Poland to close borders to foreigners, quarantine returnees, https:// www.straitstimes.com/world/europe/coronavirus-poland-to-close-borders-to-foreignersquarantine-returnees (dostęp: 1.06.2020).

Rozporządzenie Ministra Zdrowia z dnia 20 marca 2020 r. w sprawie ogłoszenia na obszarze Rzeczypospolitej Polskiej stanu epidemii, Dz. U. 2020, poz. 491.

Sieroń, A. (2020). Czy pandemia COVID-19 spowoduję zapaść globalnej gospodarki?, https:// uni.wroc.pl/czy-pandemia-covid-19-spowoduje-zapasc-globalnej-gospodarki/ (dostęp: 4.06.2020).

UDSC (Urząd do Spraw Cudzoziemców). (2020). Mapy i dane statystyczne imigrantów i stużb migracyjnych Polski, https://migracje.gov.pl (dostęp: 15.06.2020).

UNESCO (2020). Global Education Coalition, https://en.unesco.org/covid19/educationresponse/globalcoalition (dostęp: 1.06.2020).

Ustawa z dnia 14 maja 2020 r. o zmianie niektórych ustaw w zakresie działań osłonowych w związku z rozprzestrzenianiem się wirusa SARS-CoV-2, Dz. U. 2020, poz. 374, 567, 568 i 695.

WHO (World Health Organization) (2020). WHO Director-General's opening remarks at the media briefing on COVID-19-13 March 2020, https://www.who.int/director-general/ speeches/detail/who-director-general-s-opening-remarks-at-the-mission-briefing-on-covid-19-13-march-2020 (dostęp: 23.05.2020).

Unless stated otherwise, all the materials are available under 